\title{
Plants remember past weather: a study for atmospheric pollen concentrations of Ambrosia, Poaceae and Populus
}

\author{
István Matyasovszky • László Makra • Zoltán Csépe • \\ Zoltán Sümeghy • Áron József Deák • \\ Elemér Pál-Molnár • Gábor Tusnády
}

Received: 12 February 2014 / Accepted: 15 September 2014 / Published online: 9 October 2014

(C) Springer-Verlag Wien 2014

\begin{abstract}
After extreme dry (wet) summers or years, pollen production of different taxa may decrease (increase) substantially. Accordingly, studying effects of current and past meteorological conditions on current pollen concentrations for different taxa have of major importance. The purpose of this study is separating the weight of current and past weather conditions influencing current pollen productions of three taxa. Two procedures, namely multiple correlations and factor analysis with special transformation are used. The 11-year (1997-2007) data sets include daily pollen counts of Ambrosia (ragweed), Poaceae (grasses) and Populus (poplar),
\end{abstract}

\footnotetext{
I. Matyasovszky

Department of Meteorology, Eötvös Loránd University,

1117 BudapestPázmány Péter st. 1/A, Hungary

e-mail: matya@ludens.elte.hu

L. Makra $(\bowtie) \cdot$ Z. Csépe $\cdot$ Z. Sümeghy

Department of Climatology and Landscape Ecology, University of

Szeged, 6701 SzegedP.O.B. 653, Hungary

e-mail:makra@geo.u-szeged.hu

Z. Csépe

e-mail: csepzol@geo.u-szeged.hu

Z. Sümeghy

e-mail: sumeghy@geo.u-szeged.hu

Á. J. Deák

Department of Physical Geography and Geoinformatics, University of Szeged, 6701 SzegedP.O.B. 653, Hungary

e-mail: aron@geo.u-szeged.hu

E. Pál-Molnár

Department of Mineralogy, Geochemistry and Petrology, University of Szeged, 6701 SzegedP.O.B. 653, Hungary

e-mail: palm@geo.u-szeged.hu

G. Tusnády

Mathematical Institute of the Hungarian Academy of Sciences,

1364 BudapestP.O.B. 127, Hungary

e-mail: tusnady.gabor@renyi.mta.hu
}

as well as daily values of four climate variables (temperature, relative humidity, global solar flux and precipitation). Multiple correlations of daily pollen counts with simultaneous values of daily meteorological variables do not show annual course for Ambrosia, but do show definite trends for Populus and Poaceae. Results received using the two methods revealed characteristic similarities. For all the three taxa, the continental rainfall peak and additional local showers in the growing season can strengthen the weight of the current meteorological elements. However, due to the precipitation, big amount of water can be stored in the soil contributing to the effect of the past climate elements during dry periods. Higher climate sensitivity (especially water sensitivity) of the herbaceous taxa (Ambrosia and Poaceae) can be definitely established compared to the arboreal Populus. Separation of the weight of the current and past weather conditions for different taxa involves practical importance both for health care and agricultural production.

\section{Introduction}

Allergic diseases have become one of the most important health issues worldwide (Bocking et al. 2012; de Marco et al. 2012; D'Amato et al. 2013). Sensitisation and allergic diseases increase with socioeconomic status and living in large cities (Langen et al. 2013). Allergy and asthma, especially those associated with ragweed pollen, have been prevailing in Hungary (Kazinczi et al. 2008; Páldy et al. 2010). Recently, $20 \%$ of the Hungarian population suffers from pollen allergy and 60-90\% of them are sensitised with ragweed pollen (Harsányi 2009). In 1998-1999, according to skin prick tests, $83.7 \%$ of the patients were sensitive to ragweed pollen in Szeged, Hungary (Kadocsa and Juhász 2002). 
The release of allergenic pollens depends both on phytophysiological status of the given taxon and meteorological conditions. There is a vast amount of literature dealing with the relationship between daily allergenic pollen concentrations and simultaneous weather conditions (e.g. BartkováŠčevková 2003; Kasprzyk 2008; Veriankaitè et al. 2011; Prtenjak et al. 2012). The current pollen concentration is, however, affected not only by the current weather conditions but also by the effects of the antecedent meteorological conditions during a period. Taxa with short pollen seasons have longer period of past weather conditions between the last and the forthcoming pollen seasons and vice versa.

The influence of past weather conditions on certain phenological phases of different taxa has been investigated in several studies. Emberlin and Norris-Hill (1991) found that annual differences in the cumulative Urticaceae pollen concentration were primarily due to weather conditions in the period of pollen formation and only secondarily due to weather conditions in the pollen release season. Furthermore, relative humidity, temperature, wind speed and rainfall were most important in daily variations, but their relative importance varied between years. Spieksma et al. (1995) found that the air temperature during the preceding 40 days has a decisive influence on the start date of the Betula pollen season. Giner et al. (1999) related daily Artemisia pollen concentrations to the rainfall and global solar flux in the preceding weeks. They found that once pollination had begun, meteorological factors (excluding wind direction) did not seem to influence pollen concentrations significantly. Linderholm (2006) found that the timing of spring events in mid- to high-latitude plants, such as budding, leafing and flowering, is mainly regulated by temperatures after the dormancy is released. For breaking dormancy, chilling temperatures (temperatures that break dormancy) accelerate bud growth from the state of quiescence (i.e. when dormancy is broken) to the state of burst (Hänninen et al. 1993; Chuine 2000). Namely, the more chilling temperatures are received, the less forcing temperatures (temperatures that force growth during spring when dormancy has been released) are subsequently needed to reach budburst (Chuine 2000). Therefore, higher winter and early spring temperatures can produce a later onset of bud burst and pollen release. Emberlin et al. (1997) found a trend to earlier Betula pollen seasons that was related to an increase in cumulative temperatures over $5.5^{\circ} \mathrm{C}$ in January, February and March. Furthermore, they detected a significant positive relationship between the start dates of the Corylus pollen season and temperatures in October suggesting that lower temperatures in October result in an earlier onset, and vice versa (Emberlin et al. 2007). They found a significant negative association between onset and December temperatures indicating that higher December temperatures will produce an earlier onset of Corylus flowering and vice versa (Emberlin et al. 2007).
Although several studies have been published to explore the relationship between meteorological conditions and pollen loads, as well as past weather conditions and certain phenological phases of different taxa, neither of them was aimed to distinguish between the effect of current and past weather on current pollen concentrations. The purpose of this paper is to separate the weight of the current and past climate conditions in determining the pollen concentrations of Ambrosia, Poaceae and Populus for the Szeged region in the Southern Hungary applying two procedures, namely multiple correlations and factor analysis with special transformation.

\section{Materials and methods}

\subsection{Location and data}

Szeged (46.25 N; 20.10 E), the largest settlement in the southeastern Hungary is located at the confluence of the Rivers Tisza and Maros (Fig. 1). The area is characterised by an extensive flat landscape of the Great Hungarian Plain, namely Pannonian Plain, with an elevation of $79 \mathrm{~m}$ above sea level. The city is the centre of the Szeged region with 203,000 inhabitants. The climate of Szeged belongs to Köppen's Ca type (warm temperate climate) with relatively mild and short winters and hot summers (Köppen 1931).

The pollen content of the air was measured using a 7-day recording Hirst-type volumetric spore trap (Hirst 1952) (Fig. 1). The air sampler is located on top of the building of the Faculty of Arts at the University of Szeged, approximately $20 \mathrm{~m}$ above the ground surface (Makra et al. 2010).

Daily values of the current and preceding weather variables [mean temperature, $\left.\left(\mathrm{T},{ }^{\circ} \mathrm{C}\right)\right]$, relative humidity $(\mathrm{RH}, \%)$, global solar radiation $\left(\mathrm{GSR}, \mathrm{Wm}^{-2}\right)$ and precipitation amount $(\mathrm{P}$, $\mathrm{mm}$ ) influencing daily pollen concentrations were used in the study. They were collected in a meteorological station located in the inner city area of Szeged (Fig. 1). These elements were used since they indicate the highest impact on pollen production (Galán et al. 2000; Bartková-Ščevková 2003; Štefanič et al. 2005; Kasprzyk 2008; Makra and Matyasovszky 2011). The data set consists of daily pollen counts (average daily pollen count per cubic metre of air) of three taxa taken over their longest common measurement period, namely the 11-year period 1997-2007. With their Latin (English) names, they are: Ambrosia (ragweed), Poaceae (grasses) and Populus (poplar). These three taxa release the highest pollen levels, namely Ambrosia (32.6\%), Poaceae (10.4\%) and Populus (9.2\%) together account for $52.2 \%$ of the total pollen production in Szeged (Table 1).

Selection of these taxa was due to their high or medium allergenicity [in a four-score scale found in the Hungarian pollen index (www.pollenindex.hu), allergenicity of both Ambrosia and Poaceae is the highest indicated by score four, 
Fig. 1 Location of Europe including Hungary (upper panel) and the urban web of Szeged with the positions of the data sources (lower panel). Number 1 indicates the meteorological station and 2 the aerobiological station. The distance between the aerobiological and the meteorological station is $2 \mathrm{~km}$

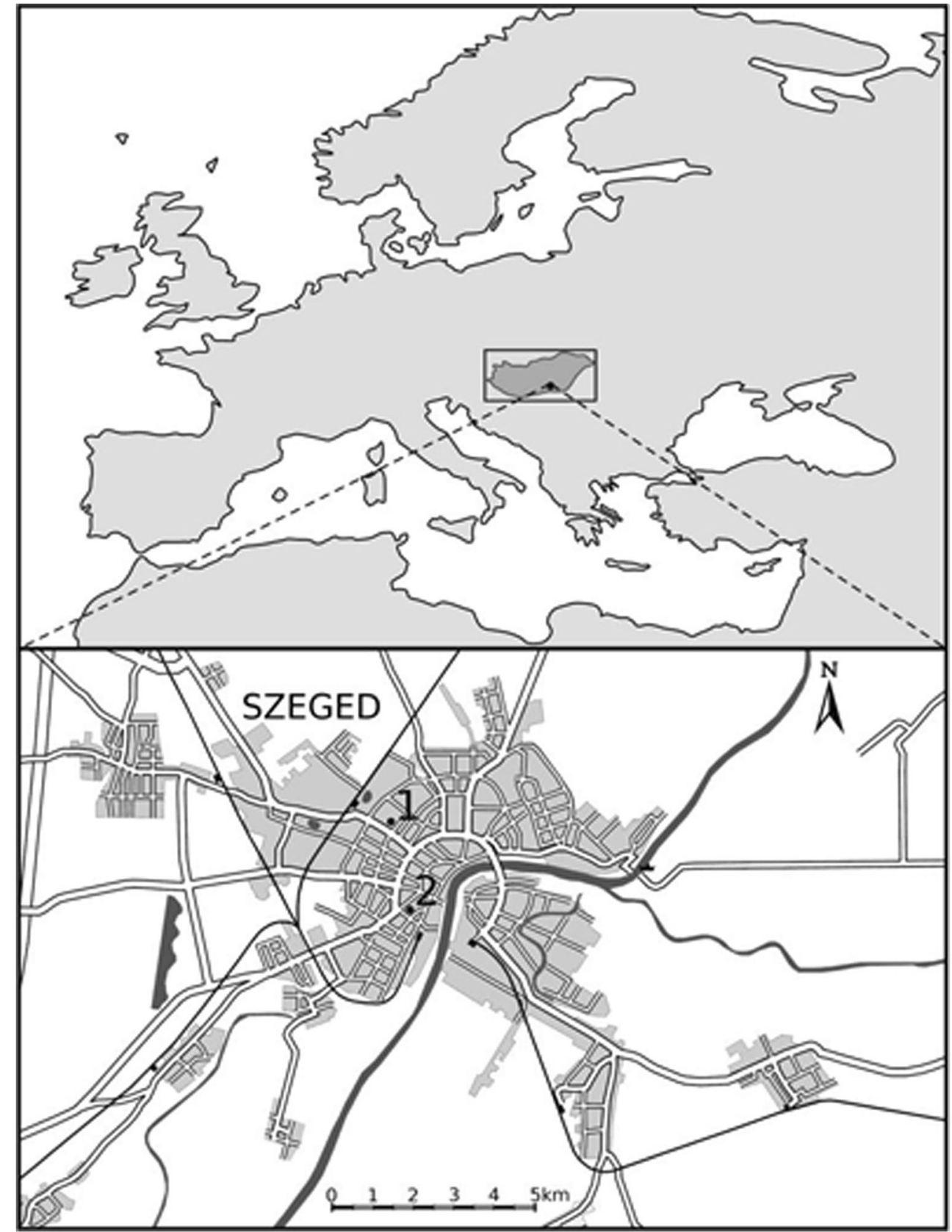

while that of Populus is medium indicated by score two] and to their more or less permanently high pollen concentrations.

Table 1 Plant habits and phenological pollen season characteristics

\begin{tabular}{llllll}
\hline Taxa & Plant habit & a Pollen level & \multicolumn{2}{l}{ Pollen season } \\
\cline { 4 - 6 } & & & Start & End & Length, day \\
\hline Ambrosia & H & 32.6 & Jul 15 & Oct 15 & 93 \\
Poaceae & H & 10.4 & Apr 16 & Oct 11 & 180 \\
Populus & AD & 9.2 & Feb 27 & Apr 20 & 53 \\
\hline
\end{tabular}

$A D$ arboreal deciduous, $H$ herbaceous

${ }^{\mathrm{a}}$ In percentage of the total pollen dispersion
Another aspect of the selection was to analyse two herbaceous taxa (Ambrosia and Poaceae) and an arboreal deciduous taxon (Populus).

Ragweed is a highly prevalent taxon not only in the Szeged area but also over the Pannonian Plain in the Carpathian Basin, as well. They occur in stubble fields, especially in sand landscapes and in abandoned places around settlements. The increase of mean temperature for the warm-tolerant Ambrosia, especially in summer time (August), leads to a limit for pollen production (Szigetvári and Benkő 2004; Béres et al. 2005). In this period, in order to preserve water, it decreases pollen production. Higher potential distribution of Ambrosia is anticipated due to its high climate tolerance. Namely, this genus 
can adapt well to dry and hot conditions. If more fallow areas and abandoned human habitats appear in the landscape, its further increase is expected, especially on sandy soils (Makra et al. 2011; Deák et al. 2013).

Both elder fallows and natural grasslands are characterised by a huge coverage of grasses, so fallow regeneration in the Szeged region led to the extension of grass-covered areas. Poaceae can produce high biomass in years with higher than usual rainfall, which is in accordance with their higher pollen production. At the same time, increased mean and maximum temperatures can cause water shortage in the driest summer period also for grasses, meaning a serious limiting factor. So they preserve water instead of producing pollen. Poaceae show high climate sensitivity. However, the species pool of this family is the widest in Hungary among the three taxa analysed in the study, so there will be other species to substitute the actual grasses, and even species from both the Mediterranean and continental areas can reach the Carpathian Basin in the future (Deák 2010; Makra et al. 2011; Deák et al. 2013).

Populus indicate a wide climate tolerance since both wet and dry tolerant species are represented in the landscape from the floodplains to the bare sand. Populus (both wild and cultivated types) were planted widely especially in the sand lands, west from Szeged city, as well as in the floodplains too. Plantation of these species has not yet stopped during the last 10 years. Besides the locust tree (Robinia pseudoacacia), they are the most favoured trees for plantation of forests. The stocks planted in the last decades have grown up; they are in mature state, so they can pollinate on high level. The warmer and moderately humid weather in the spring also favours their pollination (Deák 2010; Makra et al. 2011; Deák et al. 2013).

The pollen season is defined by its start and end dates. For the start (end) of the season, we used the first (last) date on which 1 pollen grain $\mathrm{m}^{-3}$ of air is recorded, and at least five consecutive (preceding) days also show 1 or more pollen grains $\mathrm{m}^{-3}$ (Galán et al. 2001). For a given pollen type, the longest pollen season during the 11-year period was considered for each year.

Daily values of mean temperature, relative humidity, global solar radiation and precipitation amount were labelled as current meteorological conditions for the pollen season of a given taxon, while they were considered as past meteorological conditions for the period starting from the first pollen-free day following the previous pollen season to the last pollenfree day preceding the actual pollen season.

\subsection{Regression}

Linear regressions are used in our present study as follows. The explaining variables are divided into two parts, and the daily pollen concentrations are regressed separately against these two groups of meteorological variables for every day of the pollen season. The first group includes daily values of $\mathrm{T}$,
RH, GSR and P. The second group consists of cumulative T, RH, GSR and P, which are defined as follows. Let $D$ be the duration of the pollen season of a given taxon, and let $d$ be the duration of the period from the first pollen-free day following the previous pollen season to the last pollen-free day preceding the actual pollen season. On the $i$ th day of an actual pollen season, values of the meteorological variables are accumulated from the $(i-d+j)$ th day to the $(i-1)$ th day corresponding to accumulation lengths $d-j$ for $i=1, \ldots, D$. The linear regression is carried out for every day of the pollen season $(i=1, \ldots, D)$ with every accumulation length $d-j(j=0, \ldots, d-1)$. For instance, Poaceae exhibits a pollen season in Szeged from April 16 to October 12 (Table 1 ) and thus $D=180$ and $d=186$ days. Adjusted multiple correlations (e.g. Draper and Smith 1981) for both groups of explaining variables are calculated for every day of the pollen season and every accumulation length in the past. The procedure outlined here is applied to the above-mentioned three taxa.

\subsection{Factor analysis with special transformation}

Factor analysis identifies linear relationships among examined variables and thus helps to reduce the dimensionality of a large data set of $p$-correlated variables, expressing them in terms of $m(m<p)$ new uncorrelated variables, the so-called components or factors. Calculation was based on PCA combined with varimax rotation keeping the factors uncorrelated (Sindosi et al. 2003). The number of components (factors) produced is equivalent to the number of original input variables and account for $100 \%$ of the total variance of all original variables. Since only a few components may account for the majority of the total variance, it may be unnecessary to retain all components. Several methods are available for determining the number of components to be retained (Jolliffe 1990, 1993; McGregor and Bamzelis 1995). One of the most known component selection techniques selects components with eigenvalues $>1$. This is based on the idea that all new variables should have greater explanatory power than the original variables, which have an eigenvalue of 1 . Some papers have established that selecting components with eigenvalues $<1$ can result in an increase of the explanatory power and thus suggested retaining the number of components with the largest explained cumulative variance that account for at least $80 \%$ of the total variance of the original variables that have to be explained by the factors (Jolliffe 1990). Note that these methods are considered subjective (McGregor and Bamzelis 1995). We applied the latter procedure, as perhaps the most common method, for calculating the number of components to be retained (Sindosi et al. 2003; Liu 2009). Factor analysis was applied to our initial data sets consisting of nine correlated variables (eight explanatory variables including four meteorological variables characterising the weather of actual days and the same four meteorological variables characterising the weather of 
antecedent days, as well as one resultant variable including actual daily pollen concentrations of the given taxa) in order to transform the original variables into fewer uncorrelated variables. These new variables, called factors, can be viewed as latent variables explaining the joint behaviour of the past and current meteorological elements as well as the current pollen concentration.

After performing the factor analysis, a special transformation of the retained factors was performed to find out to what degree the above-mentioned explanatory variables affect the resultant variable (daily pollen concentration) and to give a rank of their influence (Fischer and Roppert 1965; Jahn and Vahle 1968; Jolliffe 1993). In more detail, when performing factor analysis on the standardised variables, factor loadings received are correlation coefficients between the factors and the standardised original variables and, after rotation, the coordinate values belonging to the turned axes (namely, factor values). Consequently, if the resultant variable is strongly correlated with a factor (the factor has a high factor loading at the place of the resultant variable) and an influencing variable is highly correlated with the same factor, then the influencing variable is also highly correlated with the resultant variable. Accordingly, it is advisable to combine all the weights of the factors, together with the resultant variable, into a new factor. Namely, it is effective to rotate so that only one factor has great load with the resultant variable, and the remaining factors are uncorrelated with the resultant variable, that is to say, are of 0 weights. This latter procedure is called special transformation (Fischer and Roppert 1965; Jahn and Vahle 1968).

Factor analysis with special transformation is used in the study as follows. The first five variables of the abovementioned nine variables include daily pollen concentrations and daily values of T, RH, GSR and P during the pollen season of a given taxon for every year. The remaining four variables (cumulative T, RH, GSR and P) are defined as in Section 2.2, and factor analysis with special transformation is carried out for every day of the pollen season with every accumulation length in the past for each taxon, as in the case of the linear regression procedure of Section 2.2. In more detail, generating the data matrices in order to perform the factor analysis for each taxon is as follows.

The calculation procedure and main results are presented in detail for Poaceae, because this species has the longest pollen season in Hungary and has big contribution to the total annual pollen production. In order to assess the effect of the antecedent and current meteorological conditions on the current Poaceae pollen concentration, the 1st-day, 2nd-day, ..., 180th-day values of both the pollen concentration, and the four meteorological elements of the current pollen season were taken. [The duration of the Poaceae pollen season in Szeged lasts from April 16 until October 12, namely 180 days (Table 1). Namely, both for Poaceae and the remaining two pollen types; the longest pollen season during the 11-year period was considered for each year (see Section 2.1).] Furthermore, antecedent meteorological conditions in the pollen-free season preceding the actual pollen season were also considered. First take, the matrix comprising the pollen and meteorological data of the 1st day of the pollen season (April 16) for the 10-year period 1998-2007, as well as the meteorological data of the last day of the preceding pollen-free season. In this way, we receive a matrix with ten lines (ten identical days, i.e. April 16, for the 10 years, 1998-2007) and nine columns (a column for the daily pollen concentrations, four columns for the current meteorological data, i.e. daily values of T, RH, GSR and P, as well as four columns for the antecedent meteorological data, i.e. daily values of T, RH, GSR and $\mathrm{P}$, for the last day of the preceding pollen-free season). In the next steps, only the four columns for the antecedent meteorological data will change; namely, they will be the cumulated daily values of T, RH, GSR and P for the last 2, 3, .., 185 days of the preceding pollen-free season, respectively. In this way, we receive 185 matrices with ten lines and nine columns. In the following step, we consider the data matrix comprising the pollen and meteorological data of the 2nd day of the pollen season in the first five columns, and then we follow the same reasoning as above. Thereby, we receive another 185 matrices with ten lines and nine columns. Repeating this procedure 180 times, at last we receive a data matrix comprising the pollen and meteorological data of the 180th day of the pollen season in the first five columns, while the last four columns consist of the antecedent meteorological data, i.e. cumulated daily values of T, RH, GSR and $\mathrm{P}$, for the last 185 days of the preceding pollen-free season. In this way, we receive altogether $180 \times 185=33,300$ data matrices for Poaceae.

The procedure is the same for both Ambrosia and Populus. Altogether, there were $93 \times 272=25,296$ data matrices received for Ambrosia, while $53 \times 312=16,536$ for Populus.

All statistical computations were performed with MATLAB software.

Note that some of the statistical results were transferred to the figures (Figs. 2, 3, 4 and 5).

\section{Results and discussion}

Multiple correlations of daily pollen counts of the three taxa on the daily values of the meteorological variables are determined (Fig. 2). As only 11 years are available for the analysis and hence the sample size is very small, for every day, the estimated multiple correlations have big variances. In order to remove this big variability, polynomials as a function of days are fitted to the daily multiple correlation values. The optimal order of polynomials is determined by Akaike's criterion 
Fig. 2 Multiple correlations of daily pollen counts on simultaneous values of daily meteorological variables as a function of the day of the year

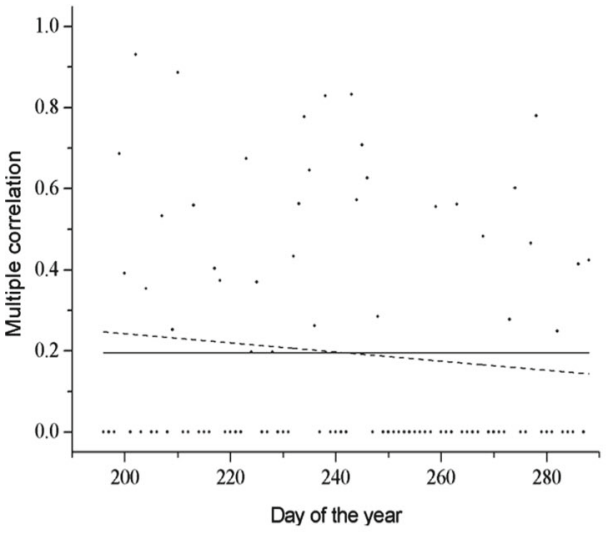

Ambrosia

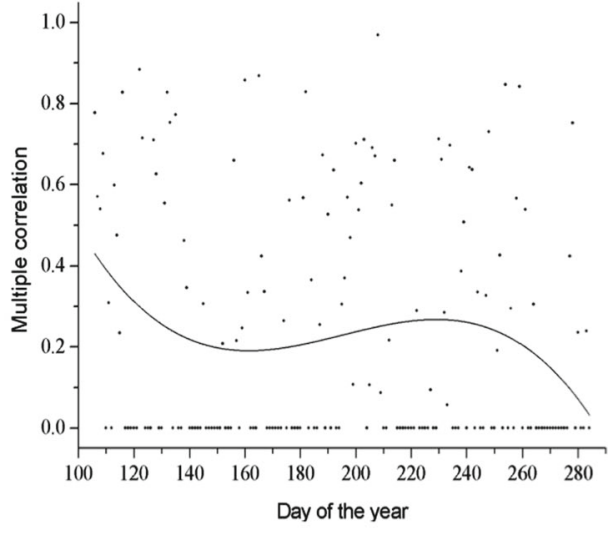

Poaceae

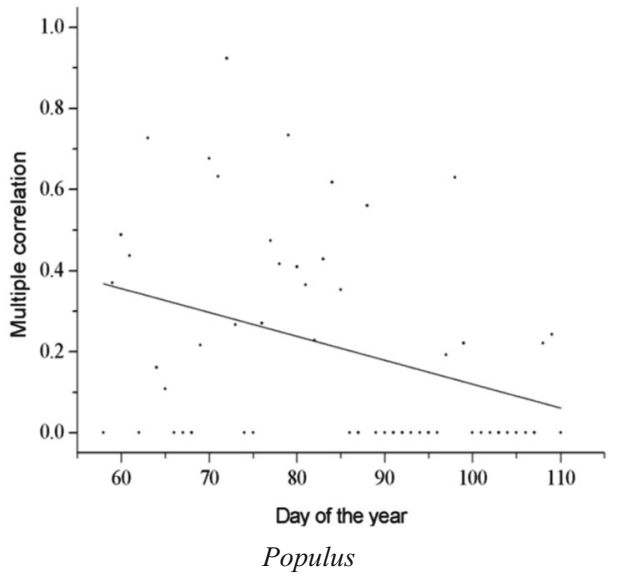

(Akaike 1974), and the significance of $t$ values corresponding to the estimated coefficients in polynomials is checked.

It can be found that multiple correlations are quite modest and do not necessarily exhibit annual cycles during the pollen seasons of the three taxa (Fig. 2). The correlation has an inclination for decrease from the beginning to the end of the pollen season for Ambrosia (dashed line), which is however not statistically significant at reasonable significance levels (somewhat higher than $10 \%$ ) based on $t$ test, so that correlations should be considered constant (solid line). Correlations for Poaceae can be best approximated by a third-order polynomial (at a significance level of $1 \%$ ) showing the highest multiple correlations at the beginning of the pollen season. A local minimum and maximum can be observed around day 159 and day 230, respectively. The lowest multiple correlations occur at the end of the pollen season. Furthermore, the correlations for Populus provide a clear decreasing trend (statistically significant at a $3.5 \%$ level) (Fig. 2).

The difference between the multiple correlations (factor loadings) of daily pollen counts on the current values of daily
Fig. 3 Difference between both the multiple correlations and factor loadings of daily pollen counts on current values of daily meteorological variables and on cumulative values of daily meteorological variables as a function of the day of the year (horizontal axis) and of the cumulation length (vertical axis), Ambrosia
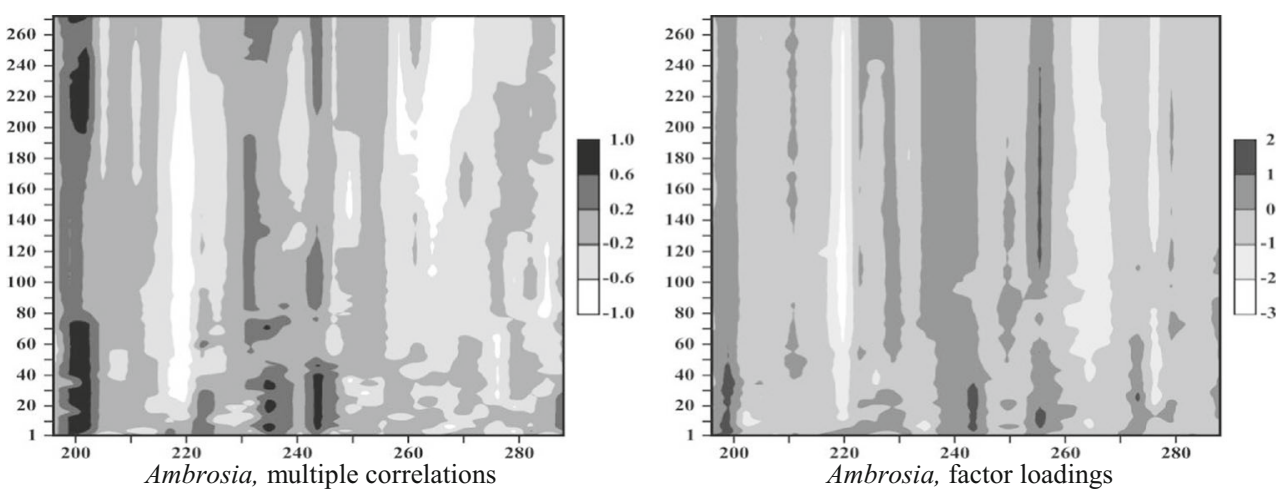
Fig. 4 Difference between both the multiple correlations and factor loadings of daily pollen counts on current values of daily meteorological variables and on cumulative values of daily meteorological variables as a function of the day of the year (horizontal axis) and of the cumulation length (vertical axis), Poaceae

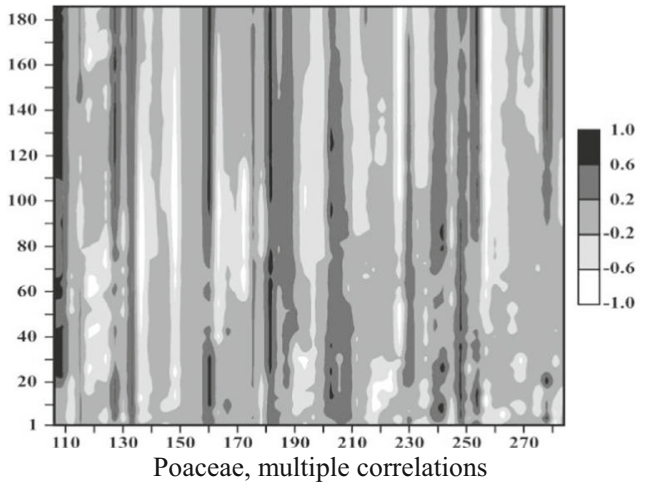

meteorological variables and on the cumulative values of daily meteorological variables as a function of the day of the year and of the accumulation length is calculated and presented in Figs. 3, 4 and 5. If the above difference is positive (negative), it indicates that the influence of the current meteorological variables on daily pollen counts is higher (lower) than the influence of the past meteorological variables.

For Ambrosia, altogether 93 (number of days of the pollen season) $\times 272$ (number of days from the first pollen-free day following the previous pollen season to the last pollen-free day preceding the actual pollen season) $=25,296$ factor analyses, while for Poaceae and Populus, 33,300 and 16,536 factor analyses with special transformations were carried out, respectively (Table 1). Namely, in total, 75,132 procedures were performed for every day of the pollen season with (1) every accumulation length for each taxon in the past, and another 75,132 procedures were carried out for every day of the pollen season with (2) every individual day for each taxon in the past. Hence, altogether, 150,264 factor analyses with special transformations were performed. However, due to the smaller variability of the associations, only those for (1) are analysed in the study (Fig. 3).

Past weather may play a relevant role in the current development of plants and their phenological phases. For instance, after extreme dry (wet) summers or years, pollen production of different taxa may decrease (increase) substantially (Láng 1998; Haraszty 2004). Accordingly, studying the effects of current and past meteorological conditions on current pollen concentrations for different taxa has major importance.

Multiple correlations of daily pollen counts on simultaneous values of daily meteorological variables have no significant dependence on the day of the year for Ambrosia. However, a clear decreasing tendency in the correlations for Populus can be explained as follows. The florescence of Populus starts earliest compared to that of the remaining two taxa. In the late February-early March, the start of florescence strongly depends on the values of the meteorological elements, basically on temperature. At the same time, in the late pollen season, the here-mentioned dependence gradually weakens that is confirmed by the absence of second florescence (Király 2009).

Correlations for Poaceae are approximated by a third-order polynomial of the day of the year. The phyto-physiological background of this association can be explained as follows. The reason of the high multiple correlations at the beginning of the pollen season in early April is due to the fill-up of the water storage of the groundwater as a result of snow melting and springtime precipitation, increasing daily mean temperatures, ceasing of night frosts and lengthening of daytimes (Láng 1998; Haraszty 2004). The here-mentioned components favour both photosynthetic and generative processes (e.g. pollen production). Due to the continental rainfall peak in summer time, pollen grains are washed out of the air; furthermore, owing to the higher cloud coverage, plants
Fig. 5 Difference between both the multiple correlations and factor loadings of daily pollen counts on current values of daily meteorological variables and on cumulative values of daily meteorological variables as a function of the day of the year (horizontal axis) and of the cumulation length (vertical axis), Populus
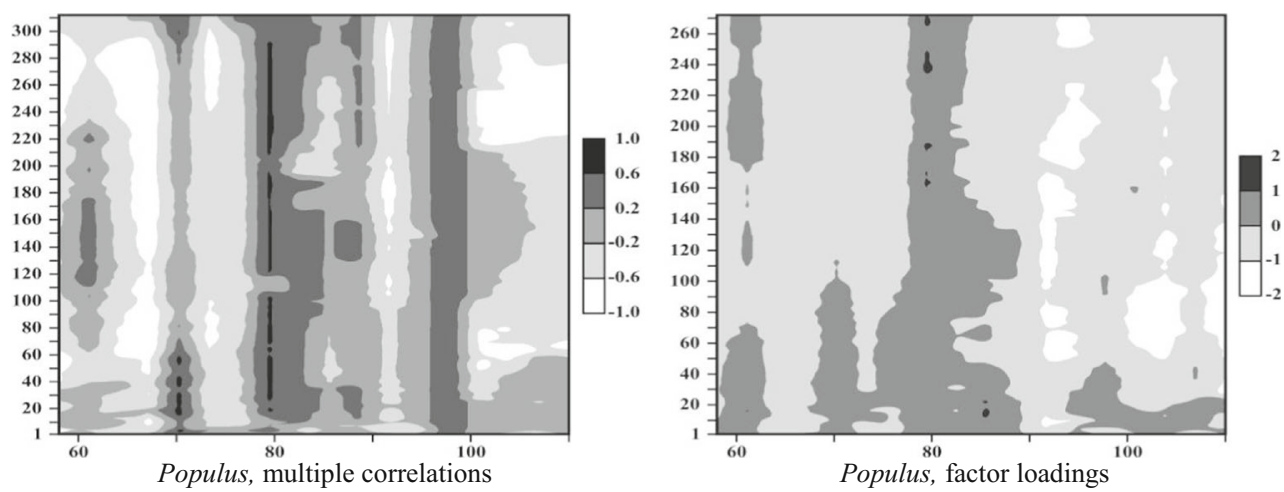
receive smaller amount of sunshine involving a decrease in photosynthesis that affects generative processes, as well. In this way, pollen production decreases in the first decade of June (Makra et al. 2011). Following the continental rainfall peak, the groundwater is restored and the cloud coverage becomes lower again activating the metabolic processes. In May, the first mowing of grasses has been occurred, so due to the continental rainfall peak, grasses are capable of regrowing again. However, in view of the higher temperatures, evapotranspiration intensifies, but plants close their stomas in order to lose less water (Makra et al. 2011). Parallel to this, the degree of photosynthesis is decreasing as they cannot assimilate as much $\mathrm{CO}_{2}$ as before. In this way, the maximum pollen production cannot reach its springtime level because less energy and organic materials can be spent to pollen production. Several grass species move to the state of a constraint rest during the summer (with withering) that is manifested in the decrease of the late summer pollen counts. This process is continued in autumn as both withered and secondly mowed grasses and grazed grasslands are unable to produce pollen anymore.

The difference between both the multiple correlations and factor loadings of daily pollen counts on the current values of daily meteorological variables and on the cumulative values of daily meteorological variables as a function of the day of the year and of the accumulation length is presented in different shadows of grey (Fig. 3). Results received using the two methods revealed characteristic similarities. Namely, extreme differences of the effects of the current and past weather elements featured by the different shades of grey indicate pronounced coincidences. This assumes that there are real associations between phyto-physiological processes on one hand and the current and past meteorological elements for given parts of the year and given accumulation lengths of days on the other.

For Ambrosia, the importance of the current meteorological conditions is clearly detected by both methods on days 198 200 and 243, while substantial concurrent negative differences with the major effect of the past meteorological conditions are emphasised by both methods on days 220, 263 and 278, though multiple correlations show only a weak and flustered character of the difference on the latter 2 days in the year (Fig. 3). For the growth of Ambrosia, the appearance of the continental rainfall peak and its degree are determining. The duration, shifts and degree of this rainy period can substantially differ year by year. This phenomenon, its occurrence or absence, influences remarkably early stages of the growth and florescence of the taxon. Additional local showers in the summer can strengthen the effect of the current meteorological elements. In warm and dry periods, the effect of the past climate elements becomes stronger that is manifested in former precipitation stored in the soil (Stefanovits 1999) (Fig. 3).
Concerning Poaceae, based on the two methods, strong simultaneous higher weight of the current meteorological conditions (positive differences with dark shade) occurs on the following days: 109, 132, 160, 181, 208, 230, 240, 249, 253 and 279. On the other hand, the important role of the past meteorological conditions (negative differences with light shade) is concurrent on days 153, 191-198, 210-212 and 247. Flowering and pollen production of Poaceae cover the whole growing season that is far much longer than those of the remaining taxa. Furthermore, Poaceae responds to robust weather events much more intensively and sensitively (Király 2009). Rainfall due to both weather fronts and local showers contributes to the development of plants and, in this way, to the increase of their pollen production. During dry periods, the groundwater ensures water supply for plants indicating the higher role of the past climate elements in these cases. The intensively stripped pattern, namely the frequent succession of the current (past) climate elements indicated by dark (light) shades shows that Poaceae is the most water sensitive of all the taxa analysed (Horváth et al. 1995) (Fig. 4).

During the heat wave over Europe in the summer 2003, with its mean temperature exceeding the 1961-1990 mean by about $5{ }^{\circ} \mathrm{C}$ in June, July and August, the grass pollen season in Switzerland was most affected starting 1-2 weeks earlier and ending 7-33 days earlier than in general. Furthermore, extreme high Poaceae daily pollen concentrations were measured in Switzerland in that pollen season (Gehrig 2006). In Hungary, due to a warming and drying climate, total annual pollen amount and annual peak pollen concentration indicate a decrease for Poaceae. At the same time, based on the daily pollen counts for Poaceae, the warmest and wettest years favour higher pollen release (Makra et al. 2012). In the Carpathian Basin involving Hungary, an extremely large number of Poaceae species occur with different starting and ending dates and duration of their lifecycles. Consequently, the effect of the meteorological elements to the pollen production is different for the different Poaceae species. In general, a moderate increase in temperature and precipitation is favourable for the pollen production of the spring species, while they have a smaller influence on summer species (Makra et al. 2012).

Considering Populus, the most important role of the current meteorological conditions with both methods can be detected concurrently on days 79-80 and day 70 but in this latter case only for the accumulation lengths of 1-100 days back from the present. At the same time, the highest concurrent weight of the past meteorological conditions occurs on days 66-68, 7374 and 92, respectively. For Populus, at the beginning of the frost-free period, predominance of the effect of the current climate elements is a characteristic for both methods. This period is the start of the growing season in Hungary. Early springtime temperatures and precipitation conditions are determining for the development of the plants. Due to the 
precipitation, a big amount of water can be stored in the soil that contributes to the increase of the effect of the past climate elements during dry periods, namely in the first and second decades of March, as well as at the beginning and the second half of April. The role of the current climate elements is strongly dominant in the third decade of March indicating an increased role of temperature and precipitation. At the same time, predominance of the effect of the current climate elements is a much less characteristic in the first half of March that can be associated with late winter frosts or early beginning of springtime (Láng 1998; Haraszty 2004) (Fig. 5).

Mean temperature, relative humidity, global solar radiation and precipitation amount as the most important meteorological factors influencing pollen production of the taxa considered are confirmed by other authors (Bartková-Ščevková 2003; Kasprzyk and Walanus 2010; Ščevková et al. 2010; Sabariego et al. 2011; Aboulaich et al. 2013). In Hungary, due to a warming and drying climate, pollen count characteristics (total annual pollen amount and annual peak pollen concentration) indicate a decrease for Ambrosia, while for Populus, an increase is expected (Makra et al. 2012). Concerning extreme weather events, the coldest and the wettest years highly facilitate Ambrosia pollen production, while both for Poaceae and Populus, the warmest and wettest years favour higher pollen release (Makra et al. 2012). Furthermore, Matyasovszky et al. (2012) established a tendency to stronger associations between the meteorological variables and the ragweed pollen variable in the pre-peak pollen season, compared to the post-peak pollen season (late summer to early autumn) that is confirmed by Giner et al. (1999) and Laaidi (2001). This is in accordance with the statement of Makra et al. (2014) who found that definitely stronger associations between the meteorological variables and the Poaceae pollen variable are found in the data sets for lower summer temperatures with near-optimum phyto-physiological processes compared to those for high and extreme high temperatures modifying life functions and, accordingly, interrelationships of the meteorological and pollen variables. This is due to the difference in the behaviour of the plants to stand environmental stress. The above findings are clearly confirmed by the decreasing multiple correlations of daily pollen counts on simultaneous values of daily meteorological variables towards the end of the pollen season for all the three taxa.

Herbaceous plants (for our case Ambrosia and Poaceae) are generally more sensitive to disturbances; however, they recover well faster compared to arboreal plants (for our case Populus) (Jones and Harrison 2004). Therefore, one may conclude that studying past meteorological conditions on these species is unnecessary. However, the recovery of these herbs from natural disturbances (e.g. floods, drought and extreme values of the climatic parameters) and human disturbances (e.g. land-use changes) is an essential factor. Seed bank and nearby propagulum sources help the regeneration processes. Since they are common plants, the lack of propagulum does not limit their fast recovery. The recovery itself can happen several times even within the year, but landscape-level local natural or human disturbances do not limit these species as they have an extended appearance and distribution in the landscape. However, for some species (e.g. for Ambrosia), human disturbances (e.g. land-use changes) are favoured and even required for the appearance and spread. We stress selecting Ambrosia, since large areas are used as arable lands in the Szeged area and the lack of proper late summer soil works can enhance their presence and spread several times, especially on sand soils. If an arable land is abandoned, Ambrosia is squeezed out fast by natural competitors of weeds and plants forming natural associations. In this way, a disturbance pattern and its degree are permanent for the analysed landscape. Herbs, especially Ambrosia, are adapted to these disturbances. Note that the sensitivity of herbs to disturbances is different, and modelling disturbances as influencing variables is very difficult. Annual trend of ragweed pollen levels in the function of the change in land use as human disturbance cannot be determined. On the other hand, change in land use for the Szeged area was negligible from the year 1990 to the year 2006 using CORINE Land Cover Database (http://www. eea.europa.eu/publications/COR0-landcover). Accordingly, land-use changes do not influence the pollen concentration of Ambrosia over the Szeged area in the period examined (Deák et al. 2013). Contrarily, extreme values of the climatic parameters as natural disturbances do affect daily pollen concentrations, and since their daily values are available, their current and past effects to the target variable can be modelled.

Accordingly, the analysis was performed for the above two herbaceous taxa as well, since it served a clear possibility for comparing the difference in the weight of both the current and past meteorological conditions on the pollen production of both herbaceous and arboreal taxa. Note that diurnal pollen concentrations of trees are much more irregular without having a clear and recurrent annual pattern than those for herbaceous taxa (Kapyla 1984; Galán et al. 1998). Furthermore, once anthesis has started in trees, it is relatively independent of weather variables (Kapyla 1984). In accordance with the above statement, higher climate sensitivity of the herbaceous taxa can be definitely established compared to that of the arboreal Populus. Namely, the frequent succession of the dark (white) strips indicating the predominance of the effect of the current (past) climate elements shows an obviously higher climate sensitivity (especially water sensitivity) for Ambrosia and Poaceae than for Populus (Figs. 3, 4 and 5).

Note that both multiple correlation analysis and factor analysis with special transformation can only be applied if it is assumed that the relationships between the variables are linear. The associations analysed in the study can be nonlinear; hence, our results are possibly distorted. However, our methodologies are capable of separating the joint effect of the 
current and past weather elements respectively, and, in this way, the results received can be considered as first steps towards discovering these nonlinear relationships.

We should remark that only 11 -year data sets were available that involve a limitation for the analysis. The difference between both the multiple correlations and factor loadings of daily pollen counts on the current values of daily meteorological variables and on the cumulative values of daily meteorological variables as a function of the day of the year and of the accumulation length was based on only 11 data on identical days of the year corresponding to the 11-year data set. Therefore, there is no sense to evaluate the statistical significance of the differences among the correlations indicated by the different shadows of grey. Hence, the short data set constrains not to involve further influencing variables.

Phyto-physiological associations of the climate parameters used are as follows. Global solar flux has a major direct effect on the photosynthetic processes, as well as an indirect effect on the plants' development through the temperature parameters. The start and run of the photosynthetic and generative processes occur in a limited range of temperature. In this way, extreme global solar flux involves too high or too low temperatures, and, due to this, the available water may limit the vegetative and generative processes (see winter and summer periods) (Makra et al. 2011; Deák et al. 2013). Concerning the four climatic parameters, the current and past components of temperature and precipitation indicate a major effect on the current pollen concentration. Long-time effect of the precipitation is manifested in the storage of groundwater or in the stored water in the plants. Relative humidity is a large variable parameter that has a rather small long-time effect on the current pollen production. An optimum relative humidity is necessary for the plants for performing generative and vegetative (e.g. photosynthesis) processes smoothly. Water captured in stomas is essential for these processes. However, optimum relative humidity assumes optimum temperature and precipitation conditions. Relative humidity has a major role only in dry climate conditions (see the Mediterranean, deserts, steppes, savannas), where the limitation or lack of groundwater is substituted partly by relative humidity. However, these conditions are not typical in the temperate belt (Láng 1998; Haraszty Á 2004; Makra et al. 2011; Deák et al. 2013). Wind speed is omitted from consideration, due to its irrelevant role as a component of the past meteorological conditions.

The association of the pollen production with the climate elements differs for the different species that is clearly represented in the study (Figs. 2, 3, 4 and 5). Its reason is that the different taxa show very different dispersal behaviour with the influencing variables used in the study (Jones and Harrison 2004).

For us, it was a really big challenge to find a way to show these associations for the readers. However, we think that at last we solved the task successfully. These figures (Figs. 3, 4 and 5) (1) show specific and unique 'imprints' of the taxa considered; namely, they are characteristics to each taxon, and, in turn, each taxon has its own 'imprint'; (2) the herementioned 'imprint' of a given taxon received using the two methodologies are surprisingly similar; (3) we can easily find that arboreal Populus shows the widest, while herbaceous Ambrosia and Poaceae, especially Poaceae, show the most narrow strips of light and dark shadows. These latter findings may denote the different sensitivity of these taxa in return to their reaction with the changing meteorological parameters. The here-mentioned findings confirm our results and ensure us that the methodologies applied highlight well the most important characteristics of the taxon-specific 'imprints'.

The question arises, whether the results received are valid for other locations as well; namely, general inferences can be drawn or they are location dependent. The inferences cannot be independent of the environmental conditions of a certain region as the species composition and metabolism features are adapted to a certain climate zone. Of course, for areas having similar species (at least genus), the composition can have similar answer to the meteorological variables involved; however, results can be interpreted just for the temperate climate zone.

The analysis of the relationship of the past values of the meteorological elements with the actual pollen season is an issue of great importance in aerobiology. Though there are some studies presenting the impact of past weather conditions on certain phenological phases of different taxa, only few papers deal with this area. Laaidi (2001) established in general that heat and enough rainfall to satisfy the water requirements during the month before pollination allow a plant to complete its development, and in particular its pollen production, and so pollinate earlier. Spieksma et al. (1995) found that the air temperature during the preceding 40 days has a decisive influence on the start date of the Betula pollen season. In Melbourne, Ong et al. (1997) used only the rainfall sum of July for developing a regression equation that predicted the beginning of grass pollination (which takes place between October 20 and November 24) with a satisfactory precision of $76 \%$. Kapyla (1984) and Galán et al. (1998) detected that diurnal pollen concentrations of trees were much more irregular without having a clear and recurrent annual pattern than those of herbaceous taxa. Furthermore, once anthesis has started in trees, it is relatively independent of weather variables (Kapyla 1984). Emberlin and Norris-Hill (1991) established that annual differences in the cumulative Urticaceae pollen concentration were primarily due to weather conditions in the period of pollen formation and only secondarily due to weather conditions in the pollen release season. Furthermore, relative humidity, temperature, wind speed and rainfall were most important in daily variations, but their relative importance varied between years. Giner et al. 
(1999) associated daily Artemisia pollen concentrations to the rainfall and global solar flux in the preceding weeks. They found that once pollination had begun, meteorological factors (excluding wind direction) did not seem to influence pollen concentrations significantly. In order to group years according to the allergenic potential of airborne Poaceae pollen, Sánchez Mesa et al. (2005) separated winter variables from early spring variables when considering pre-season meteorological variables, due to the nature of the Mediterranean climate. However, this was a similar but not the same step applied in this study, namely separating the weight of the current and antecedent meteorological variables.

It is to be mentioned that not all possible influencing variables were considered and perhaps not the most influential variables were used in the study. Namely, time-dependent daily pollen concentrations are influenced by numerous other underlying processes, as well. They include (1) genetic attributes, (2) soil type including location-specific nutrient availability, (3) meteorological conditions in the root zone, (4) land-use changes, (5) current and preceding weather variables, (6) the height of the planetary boundary layer (PBL) and the ventilation coefficient, (7) long-range pollen transport, (8) resuspension of the pollen grains, (9) disruption of the pollen grains and (10) pollen grains as condensation nuclei. Since some of the above parameters are either constant for a given taxon (1), or can be neglected (4), or not available $(3,6)$, or are hard to model $(2,8,9)$ or difficult to consider their effect when assessing the target variable $(7,10)$, they were omitted from further consideration. However, acknowledging the limiting factors mentioned above, this is the first approach to separate the weight of the current and past weather elements in determining the current local pollen production of two herbaceous taxa and the arboreal Populus.

Separation of the weight of the current and past climate conditions for different taxa presented in the study involves practical importance not only for pollen-sensitised people but also for agricultural production. Namely, the knowledge of taxon specific effects of the past weather depending in time may help to predict future pollen levels well ahead in time; furthermore, it may contribute to reduce weather dependence of agricultural production.

Acknowledgments The authors would like to thank Gábor Motika (Environmental Conservancy Inspectorate, Szeged, Hungary) for providing the meteorological data of Szeged and Miklós Juhász (University of Szeged) for providing the daily pollen concentration data of Szeged. This research was supported by the European Union and the State of Hungary, cofinanced by the European Social Fund in the framework of TÁMOP 4.2.4. A/2-11-1-2012-0001 'National Excellence Program'.

\section{References}

Aboulaich N, Achmakh L, Bouziane H, Trigo MM, Recio M, Kadiri M, Cabezudo B, Riadi H, Kazzaz M (2013) Effect of meteorological parameters on Poaceae pollen in the atmosphere of Tetouan (NW Morocco). Int J Biometeorol 57(2):197-205

Akaike H (1974) A new look at the statistical model identification. IEEE Trans Autom Control 19(6):716-723

Bartková-Ščevková J (2003) The influence of temperature, relative humidity and rainfall on the occurrence of pollen allergens (Betula, Poaceae, Ambrosia artemisiifolia) in the atmosphere of Bratislava (Slovakia). Int J Biometeorol 48(1):1-5

Béres I, Novák R, Hoffmanné Pathy, Zs., Kazinczi, G. (2005). Az ürömlevelü parlagfü (Ambrosia artemisiifolia L.) elterjedése, morfológiája, biológiája, jelentősége és a védekezés lehetőségei. [Distribution, morphology, biology and importance of common ragweed (Ambrosia artemisiifolia L.) and protection facilities.] Gyomnövények, Gyomirtás, 6, 1-48. (in Hungarian)

Bocking C, Renz H, Pfefferle PI (2012) Prevalence and socio-economic relevance of allergies in Germany. BundesgesundheitsblattGesundheitsforschung-Gesundheitsschutz 55(3):303-307

Chuine I (2000) A unified model for budburst of trees. J Theor Biol 207: $337-347$

D’Amato G, Baena-Cagnani CE, Cecchi L, Annesi-Maesano I, Nunes C, Ansotegui I, et al. (2013) Climate change, air pollution and extreme events leading to increasing prevalence of allergic respiratory diseases. Multidisciplinary Respiratory Medicine, Vol. 8, Article No. 12

Deák JÁ (2010) Csongrád megye kistájainak élőhelymintázata és tájökológiai szempontú értékelése. (Habitat-pattern and landscape ecological evaluation of the microregions of Csongrád county.) $P h D$ Dissertation, University of Szeged, 125 p. (in Hungarian)

Deák JÁ, Makra L, Matyasovszky I, Csépe Z, Muladi B (2013) Climate sensitivity of allergenic taxa in Central Europe associated with new climate change-related forces. Sci Total Environ 442:36-47

de Marco R, Cappa V, Accordini S, Rava M, Antonicelli L, Bortolami O et al (2012) Trends in the prevalence of asthma and allergic rhinitis in Italy between 1991 and 2010. Eur Respir J 39(4):883-892

Draper N, Smith H (1981) Applied regression analysis, 2nd edn. Wiley, New York

Emberlin J, Norris-Hill J (1991) Annual, daily and diurnal variation of Urticaceae pollen in North-Central London. Aerobiologia 7(1):49 56

Emberlin J, Mullins J, Corden J, Millington W, Brooke M, Savage M et al (1997) The trend to earlier birch pollen seasons in the U.K.: a biotic response to changes in weather conditions? Grana 36(1):29-33

Emberlin J, Smith M, Close R, Adams-Groom B (2007) Changes in the pollen seasons of the early flowering trees Alnus spp. and Corylus spp. in Worcester, United Kingdom, 1996-2005. Int J Biometeorol 51(3):181-191

Fischer G, Roppert J (1965) Ein Verfahren der Transformationsanalyse faktorenanalytischer Ergebnisse. In: Lineare Strukturen in Mathematik und Statistik unter besonderer Berücksichtigung der Faktoren- und Transformationsanalyse. Arbeiten aus dem Institut für höhere Studien und wissenschaftliche Forschung. Wien Verlag Physica, Wien-Würzburg, 1. (in German)

Galán C, Fuillerat MJ, Comtois P, Domínguez-Vilches E (1998) Bioclimatic factors affecting daily Cupressaceae flowering in southwest Spain. Int J Biometeorol 41(3):95-100

Galán C, Alcázar P, Cariňanos P, Garcia H, Domínguez-Vilches E (2000) Meteorological factors affecting daily Urticaceae pollen counts in southwest Spain. Int J Biometeorol 43(4):191-195

Galán C, Cariňanos P, García-Mozo H, Alcázar P, Domínguez-Vilches E (2001) Model for forecasting Olea europaea L. airborne pollen in South-West Andalusia, Spain. Int J Biometeorol 45(2):59-63 
Gehrig R (2006) The influence of the hot and dry summer 2003 on the pollen season in Switzerland. Aerobiologia 22(1):27-34

Giner MM, García JSC, Sellés JG (1999) Aerobiology of Artemisia airborne pollen in Murcia (SE Spain) and its relationship with weather variables: annual and intradiurnal variations for three different species. Wind vectors as a tool in determining pollen origin. Int J Biometeorol 43(2):51-63

Hänninen H, Kellomäki S, Laitinen K, Pajari B, Repo T (1993) Effect of increased winter temperature on the onset of height growth of Scots pine: a field test of a phenological model. Silva Fennica 27(4):251257

Harsányi E (2009) Parlagfü és allergia. (Ragweed and allergy.). Növényvédelem 45(8):454-458 (in Hungarian)

Hirst JM (1952) An automatic volumetric spore trap. Ann Appl Biol 39(2):257-265

Haraszty Á (ed.) (2004) Növényszervezettan és növényélettan. (Plant Anatomy and Plant Physiology.) Budapest: Nemzeti Tankönyvkiadó. (in Hungarian)

Horváth F, Dobolyi ZK, Morschhauser T, Lőkös L, Karas L, Szerdahelyi T (1995) Flóra adatbázis. (Flora database.) 1.2. Vácrátót: MTAÖBKI. (in Hungarian)

Jahn W, Vahle H (1968) Die Faktoranalyse und ihre Anwendung. Verlag die Wirtschaft, Berlin (in German)

Jolliffe IT (1990) Principal component analysis: a beginner's guide- - I. Introduction and application Weather 45(10):375-382

Jolliffe IT (1993) Principal components analysis: a beginner's guide-II. Pitfalls, myths and extensions. Weather 48(8):246-253

Jones AM, Harrison RM (2004) The effects of meteorological factors on atmospheric bioaerosol concentrations - a review. Sci Total Environ 326:151-180

Kadocsa E, Juhász M (2002) Study of airborne pollen composition and allergen spectrum of hay fever patients in South Hungary (19901999). Aerobiologia 18(3-4):203-209

Kapyla M (1984) Diurnal variation of tree pollen in the air in Finland. Grana 23(3):167-176

Kasprzyk I (2008) Non-native Ambrosia pollen in the atmosphere of Rzeszow (SE Poland): evaluation of the effect of weather conditions on daily concentrations and starting dates of the pollen season. Int J Biometeorol 52(5):341-351

Kasprzyk I, Walanus A (2010) Description of the main Poaceae pollen season using bi-Gaussian curves, and forecasting methods for the start and peak dates for this type of season in Rzeszow and Ostrowiec Sw. (SE Poland). J Environ Monit 12(4):906-916

Kazinczi G, Béres I, Pathy Z, Novák R (2008) Common ragweed (Ambrosia artemisiifolia): a review with special regards to the results in Hungary: II. Importance and harmful effect, allergy, habitat, allelopathy and beneficial characteristics. Herbologia 9(1):94 118

Király G (ed.) (2009) Új magyar füvészkönyv I-II. Magyarország hajtásos növényei. Határozókulcsok. (New Hungarian grass book I-II. Shooted plants of Hungary. Adverbs keys.) Jósvafö: Aggteleki Nemzeti Park Igazgatóság. (in Hungarian)

Köppen W (1931) Grundriss Der Klimakunde. Walter De Gruyter \& Co., Berlin (in German)

Laaidi M (2001) Forecasting the start of the pollen season of Poaceae: evaluation of some methods based on meteorological factors. Int $\mathrm{J}$ Biometeorol 45(1):1-7

Láng F (ed.) (1998). Növényélettan. A növényi anyagcsere. (Plant physiology. Metabolism of plants.) Budapest: ELTE Eötvös Kiadó. (in Hungarian)

Langen U, Schmitz R, Steppuhn H (2013) Prevalence of allergic diseases in Germany. Results of the German Health Interview and Examination Survey for Adults (DEGS1). BundesgesundheitsblattGesundheitsforschung-Gesundheitsschutz 56:698-706

Linderholm HW (2006) Growing season changes in the last century. Agric For Meteorol 37(1-2):1-14
Liu PWG (2009) Simulation of the daily average PM10 concentrations at Ta-Liao with Box-Jenkins time series models and multivariate analysis. Atmos Environ 43(13):2104-2113

Makra L, Sánta T, Matyasovszky I, Damialis A, Karatzas K, Bergmann $\mathrm{KC}$ et al (2010) Airborne pollen in three European cities: detection of atmospheric circulation pathways by applying three-dimensional clustering of backward trajectories. J Geophys Res Atmos 115: D24220. doi:10.1029/2010JD014743

Makra L, Matyasovszky I (2011) Assessment of the daily ragweed pollen concentration with previous-day meteorological variables using regression and quantile regression analysis for Szeged, Hungary. Aerobiologia 27(3):247-259

Makra L, Matyasovszky I, Deák JÁ (2011) Trends in the characteristics of allergenic pollen circulation in Central Europe based on the example of Szeged, Hungary. Atmos Environ 45(33):6010-6018

Makra L, Matyasovszky I, Páldy A, Deák JÁ (2012) The influence of extreme high and low temperatures and precipitation totals on pollen seasons of Ambrosia, Poaceae and Populus in Szeged, southern Hungary. Grana 51(3):215-227

Makra L, Csépe Z, Matyasovszky I, Deák ÁJ, Pál-Molnár E, Tusnády G (2014) Interdiurnal variability of Artemisia, Betula and Poaceae pollen counts and their association with meteorological parameters. Carpathian J Earth Environ Sci 9(3):207-220

Matyasovszky I, Makra L, Csépe Z (2012) Associations between weather conditions and ragweed pollen variations in Szeged, Hungary. Arch Ind Hyg Toxicol (Arhiv Za Higijenu Rada I Toksikologiju) 63(3): 311-320

McGregor GR, Bamzelis D (1995) Synoptic typing and its application to the investigation of weather-air pollution relationships, Birmingham, United Kingdom. Theor Appl Climatol 51(4):223236

Ong EK, Taylor PE, Knox RB (1997) Forecasting the onset of the grass pollen season in Melbourne (Australia). Aerobiology 13(1):43-48

Páldy A, Bobvos J, Magyar D, Nékám K, Bitay Z, Csajbók V et al (2010) Parlagfüallergia. A parlagfú pollinózis - a poliszenzitizáltság kezdete? (Ragweed allergy. Ragweed pollinosis - the start of the pollen sensitivity?). Egészségtudomány 54(4):47-55 (in Hungarian)

Prtenjak MT, Srnec L, Peternel R, Madzarevic V, Hrga I, Stjepanovic B (2012) Atmospheric conditions during high ragweed pollen concentrations in Zagreb, Croatia. Int J Biometeorol 56(6):1145-1158

Sabariego S, Pérez-Badia R, Bouso V, Gutiérrez M (2011) Poaceae pollen in the atmosphere of Aranjuez, Madrid and Toledo (central Spain). Aerobiologia 27(3):221-228

Sánchez Mesa JA, Galán C, Hervás C (2005) The use of discriminant analysis and neural networks to forecast the severity of the Poaceae pollen season in a region with a typical Mediterranean climate. Int J Biometeorol 49(6):355-362

Ščevková J, Dušička J, Chrenová J, Mičieta K (2010) Annual pollen spectrum variations in the air of Bratislava (Slovakia): years 20022009. Aerobiologia 26(4):277-287

Sindosi OA, Katsoulis BD, Bartzokas A (2003) An objective definition of air mass types affecting Athens, Greece; the corresponding atmospheric pressure patterns and air pollution levels. Environ Technol 24(8):947-962

Štefanič E, Kovačevič V, Lazanin Ž (2005) Airborne ragweed pollen concentration in north-eastern Croatia and its relationship with meteorological parameters. Ann Agric Environ Med 12(1):75-79

Spieksma FTM, Emberlin JC, Hjelmroos M, Jäger S, Leuschner RM (1995) Atmospheric birch (Betula) pollen in Europe - trends and fluctuations in annual quantities and the starting dates of the seasons. Grana 34(1):51-57

Stefanovits P (1999) A talajok osztályzása. Főtípusok, típusok és altípusok. (Classiciation of soils. Main types, types and sub-types.) In: P. Stefanovits, Gy. Filep, Gy. Füleky (Eds.), Talajtan (Soil science) (pp. 239-314.) Budapest: Mezőgazda Kiadó. (in Hungarian) 
Szigetvári Cs, Benkő ZsR (2004) Ürömlevelü parlagfü (Ambrosia artemisiifolia). pp. 337-370. In: Mihály B, Botta-Dukát Z (eds.) Özönnövények-Biológiai Inváziók Magyarországon. (Invasive Plants - Biological Invasions in Hungary.) A KvVM Természetvédelmi Hivatalának Tanulmánykötetei, (Essays of the Conservation Agency of the Ministry of Environment and Water),
9. TermészetBúvár Alapítvány Kiadó, Budapest, 408 p. ISBN: 9638610751 (in Hungarian)

Veriankaitè L, Šaulienè I, Bukantis, A. (2011) Evaluation of meteorological parameters influence upon pollen spread in the atmosphere. $\mathrm{J}$ Enviro Eng Landsc Manag 19(1), 5-11. www. pollenindex.hu http:// www.eea.europa.eu/publications/COR0-landcover 